\title{
Synthesis and solvodynamic diameter measurements of closely related mannodendrimers for the study of multivalent carbohydrate-protein interactions
}

\author{
Yoann M. Chabre, Alex Papadopoulos, Alexandre A. Arnold and René Roy
}

\section{Full Research Paper}

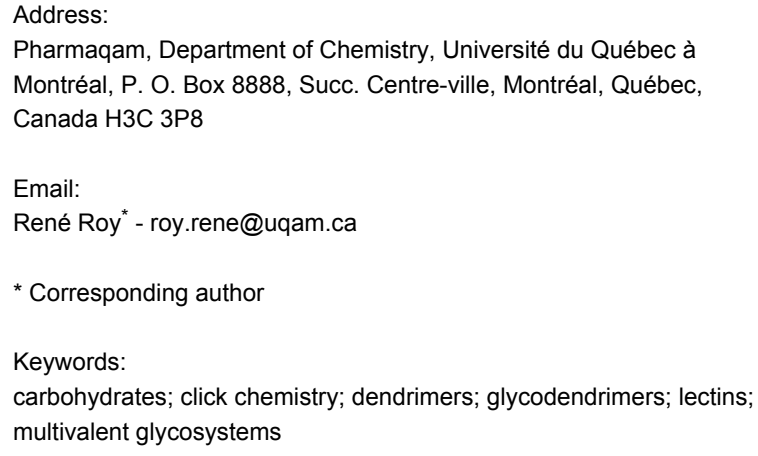

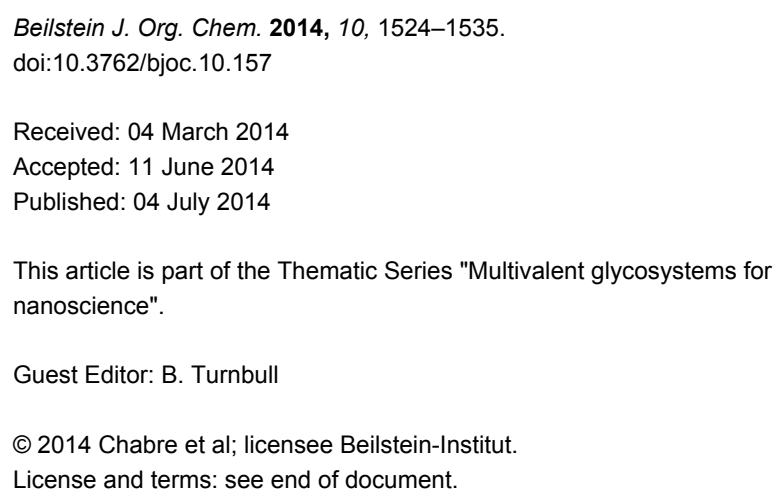

\begin{abstract}
This paper describes the synthesis of three closely related families of mannopyranoside-containing dendrimers for the purpose of studying subtle structural parameters involved in the measurements of multivalent carbohydrate-protein binding interactions. Toward this goal, two trimers 5 and $\mathbf{9}$, three 9-mers 12, 17, 21, and one 27-mer 23, varying by the number of atoms separating the anomeric and the core carbons, were synthesized using azide-alkyne cycloaddition (CuAAc). Compound $\mathbf{2 3}$ was prepared by an efficient convergent strategy. The sugar precursors consisted of either a 2-azidoethyl (3) or a prop-2-ynyl $\alpha$-D-mannopyranoside (7) derivative. The solvodynamic diameters of 9-mer 12, 17, and 21 were determined by pulsed-field-gradient-stimulated echo (PFGSTE) NMR experiments and were found to be $3.0,2.5$, and $3.4 \mathrm{~nm}$, respectively.
\end{abstract}

\section{Introduction}

Multivalent carbohydrate-protein interactions are at the forefront of a wide range of biological events which have triggered a plethora of versatile synthetic methods for the design of potent inhibitors and glycomimetics [1-4]. Among the diverse strategies leading to efficient ligands, glycopolymers [1,5-7], glycodendrimers [7-14], and sugar rods [15,16] have retained most attention. An additional approach that has gained keen interest resides in the modifications of both the aglycon [17-19] and substituent residues [20-22] of the targeted sugar moieties through extensive studies of quantitative structure-activity relationships (QSARs). In most of the studies related to aglycon modifications, it was concluded that aromatic glycosides possessed improved binding properties due to the ubiquitous presence of aromatic amino acids in the cognate binding sites 
[23-25]. This is also supported by the recent findings that the sugar backbones themselves also possess a hydrophobic side that orients the sugars in appropriate aromatic amino acid rich pockets [26-28].

Unfortunately, due to the inherent complexity of studying multivalent binding interactions, researchers have used experimental conditions that often biased the intrinsic phenomena under investigations [29]. For instance, when evaluating thermodynamic parameters by isothermal calorimetry (ITC), scientists used either truncated versions of for instance, tetrameric lectins such as ConA, or diluted conditions to avoid precipitation of the complexes $[30,31]$. Alternatively, the application of surface plasmon resonance (SPR) also creates artificial situations not sufficiently related to the natural cellular events, thus requiring complex mathematical algorithms [32]. Most solidphase immunoassays (ELLA, ELISA) also fall under the same criticism by providing unusually high (or too close) sugar densities. Also important and in spite of the two decades of glycodendrimer chemistry [7], there is still no general rule to allow predicting which structural parameters would be optimal for the binding interactions.

In order to gain more insight into this direction, we designed herein three families of closely related mannopyranoside clusters (glycodendrimers) aimed at evaluating their relative binding abilities against the hometetrameric leguminous lectin ConA from Canavalia ensiformis by inhibition of haemagglutination and by turbidimetry. The latter would allow us to measure relative kinetic factors involved in the cross-linking lattice formation using soluble partners.

\section{Results and Discussion}

In order to critically evaluate the subtle structural parameters imparted by glycodendrimers in deciphering their relative thermodynamic and kinetic abilities towards multivalent lectins, we designed three families of closely related mannopyranoside dendrimers. Scheme 1 describes the preparation of trimers $\mathbf{5}$ and 9 built around benzene-1,3,5-tricarboxamide (BTA or trimesamide core) having respectively nine and ten atoms between the

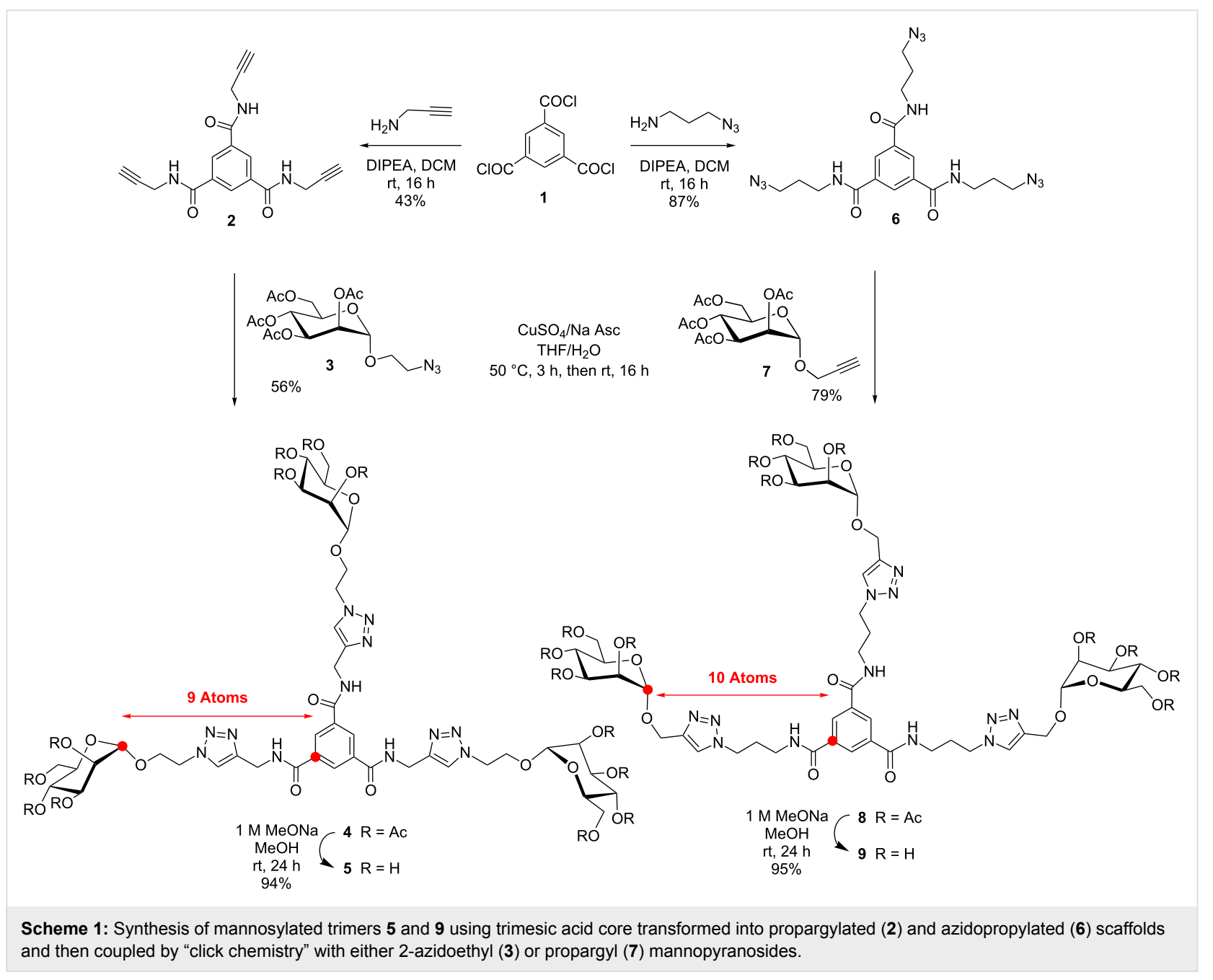


anomeric and the benzene carbon, hence differing by a distance of only $\sim 1.5 \AA$. Schemes $2-4$ illustrate the syntheses of 9-mers 12 and 21 using the same trimesic acid core, together with a phloroglucinol template to initiate the synthesis of homologue 17, but incorporating 2-amino-2-hydroxymethylpropane-1,3diol as a branching unit (TRIS) at the G(1) level. Thus, compounds 12, 17, and 21 differ by having nine atoms between the anomeric carbon and the focal quaternary carbon of TRIS followed by two, four, and nine atoms to reach the benzene carbon, respectively $(\sim 4,6$, and $12 \AA)$. Finally, the synthesis of a 27-mer mannosylated dendrimer $\mathbf{2 3}$ is shown in Scheme 5.
The synthesis of $\mathbf{5}$ was accomplished starting from commercial trimesic acid chloride $\mathbf{1}$ which was readily transformed into known tripropargyl amide derivative 2 [33] using propargylamine according to Scheme 1. Amide 2 was conjugated to peracetylated 2-azidoethyl $\alpha$-D-mannopyranoside 3 [34] under classical copper-catalyzed dipolar cycloaddition (CuAAc) to afford 4 in $56 \%$ yield. Structure 4 was readily characterized by the absence of acetylenic protons at $\delta 3.16 \mathrm{ppm}$, the appearance of identical triazole protons $(3 \mathrm{H})$ at $\delta 7.74 \mathrm{ppm}$ relative to the anomeric signal $(3 \mathrm{H})$ at $\delta 4.81 \mathrm{ppm}$ and corresponding HRMS data. Zemplén deprotection $(\mathrm{NaOMe}, \mathrm{MeOH})$ afforded 5 in

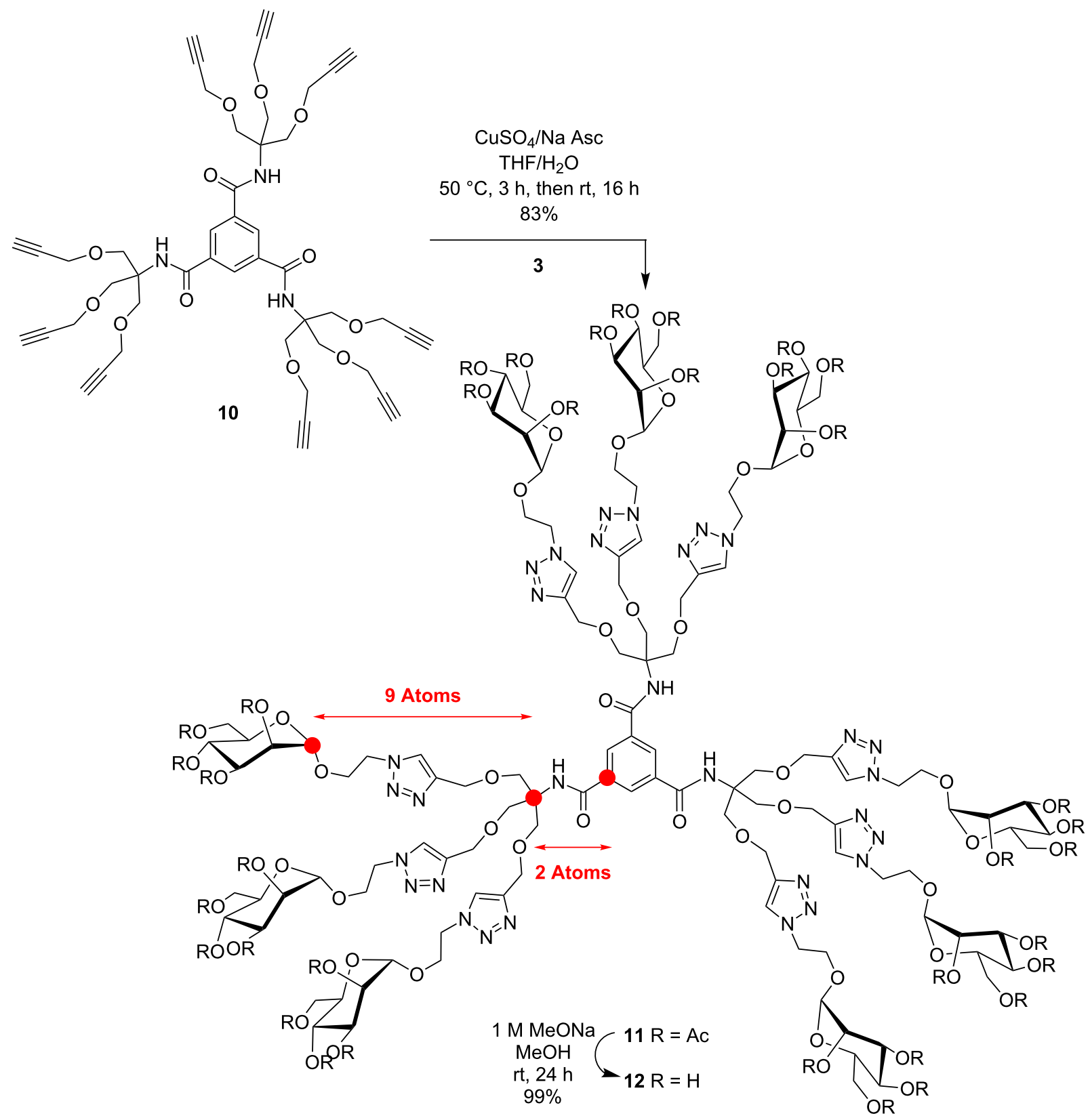


94\% yield. Synthesis of the related homolog 9, prepared in 74\% overall yield from known 6 [17] by an analogous click chemistry, is also described in Scheme 1. To this end, trichloride 1 was treated as above with 3-azido-1-propanamine to provide 6 in $87 \%$ yield. Azide-alkyne cycloaddition of $\mathbf{6}$ with prop-2-ynyl $\alpha$-D-mannopyranoside 7 [35] gave 8 (79\%) which was de- $O$ acetylated under Zemplén conditions (NaOMe, $\mathrm{MeOH}, 95 \%$ ) to give 9.
The syntheses of 9-mers 12, 17 and $\mathbf{2 1}$ are illustrated in Schemes 2-5 and follow a conceptually identical strategy to the one described above for trimers 5 and 9. Toward this goal, propargylated 9-mer scaffold $\mathbf{1 0}$ [17] was treated under the same CuAAc conditions with azide 3 to provide peracetylated 11 in $83 \%$ yield which upon Zemplén de- $O$-acetylation gave 12 in essentially quantitative yield (Scheme 2). Complete spectral characterization $\left({ }^{1} \mathrm{H},{ }^{13} \mathrm{C}\right.$ NMR and HRMS $)$ concluded for the

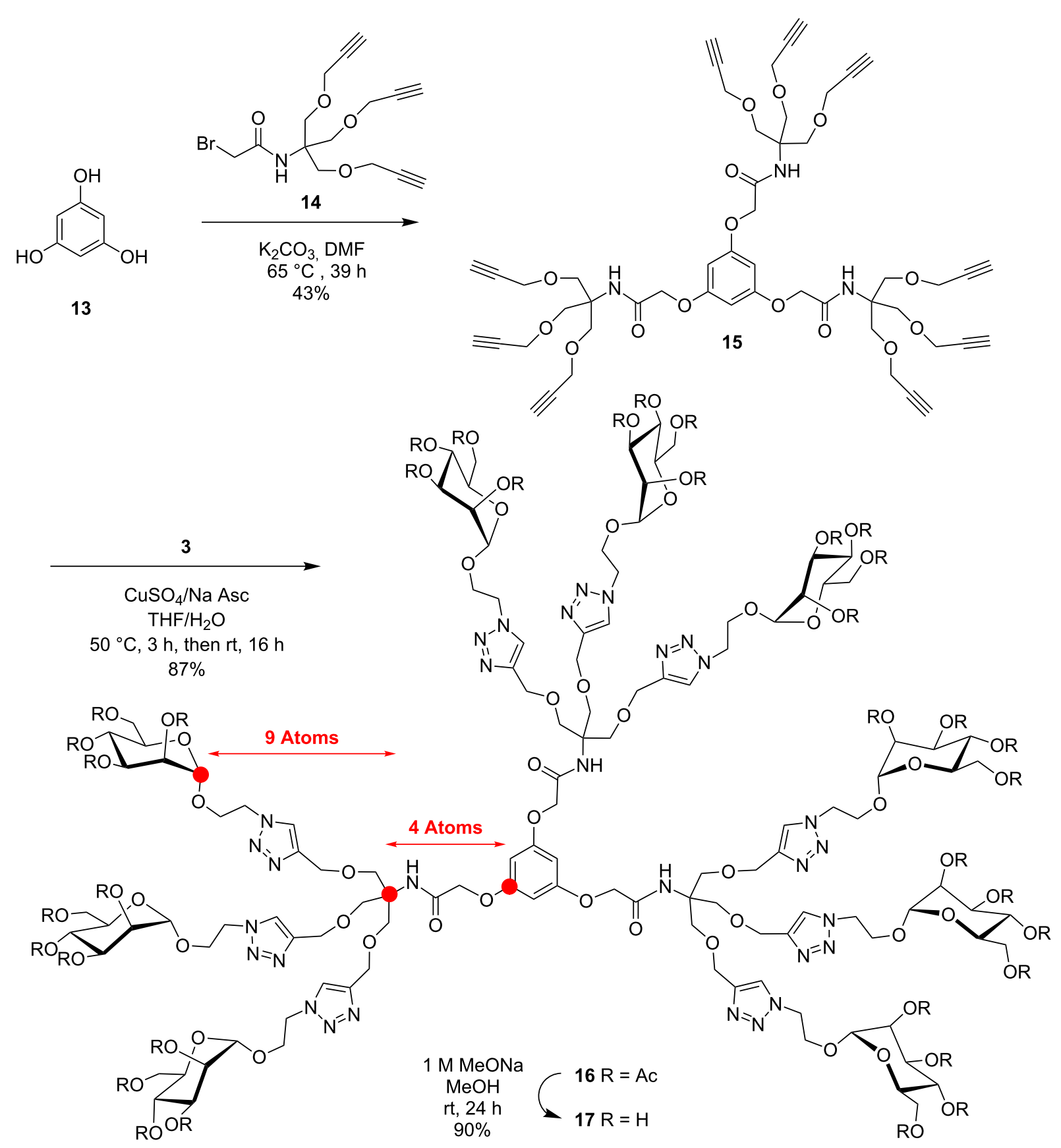

Scheme 3: Divergent CuAAc synthesis of "extended" 9-mer 17 using phloroglucinol (13) as core, bromoacylated TRIS as linker and mannopyranosylazide 3 . 
aforementioned structure having twelve atoms in the linking arm (see Supporting Information File 1).

Analogously, the extended 9-mer glycodendrimer 17, possessing fourteen atoms between the anomeric carbon and the benzene carbon, was prepared according to Scheme 3. Thus, phloroglucinol (13) was carefully $O$-alkylated with the previously synthesized bromoacetylated TRIS derivative 14 [36] using $\mathrm{K}_{2} \mathrm{CO}_{3}$ in DMF to provide 15 in $43 \%$ yield. Again, the structural integrity of $\mathbf{1 5}$ was fully assessed by the simplicity of its ${ }^{1} \mathrm{H}$ NMR symmetrical patterns that showed the characteristic singlets for the three amide protons at $\delta 6.85 \mathrm{ppm}$, relative to the three benzene protons $(\delta 6.17 \mathrm{ppm})$ and the six $O$-acyl protons at $\delta 4.36 \mathrm{ppm}$ (core) compared with the peripheral acetylenic methylenes $(18 \mathrm{H})$, inner methylene of TRIS $(18 \mathrm{H})$, and the terminal alkyne protons $(9 \mathrm{H})$ at $\delta 4.16,3.87$, and $2.48 \mathrm{ppm}$, respectively.

Toward the last and further extended 9-mer 21, a convergent strategy was rather adopted (Scheme 4). This strategy has the clear advantages of providing an easier purification process from partially substituted end-products together with a better assessment of complete surface group modifications. Hence, known 14 [36] was first cycloadded to mannosylazide 3 under the above CuAAc conditions. The "click reaction" proceeded exceptionally efficiently and provided bromoacylated dendron precursor 18 in $94 \%$ yield. Substitution of the bromide by azide also proceeded uneventfully $\left(\mathrm{NaN}_{3}, \mathrm{DMF}, \mathrm{rt}, 16 \mathrm{~h}\right)$ to afford intermediate glycodendron 19 in $93 \%$ yield. Finally, coupling of the propargylated core $\mathbf{2}$ with azidodendron 19 under the typical CuAAc conditions gave peracetylated intermediate $\mathbf{2 0}$ which was readily deprotected to give 9 -mer 21 in $84 \%$ overall yield. All spectral characteristics concurred to the expected structural integrity of $\mathbf{2 1}$ (see Supporting Information File 1).

Finally, a 27-mer mannosylated G(1)-dendrimer 23 was similarly prepared using an accelerated convergent strategy (Scheme 5). This time, the nonapropargylated scaffold 10 was "clicked" under CuAAc with trimeric azidodendron 19 to give $\mathbf{2 2}$ in an acceptable yield of $63 \%$ after silica gel column chro-

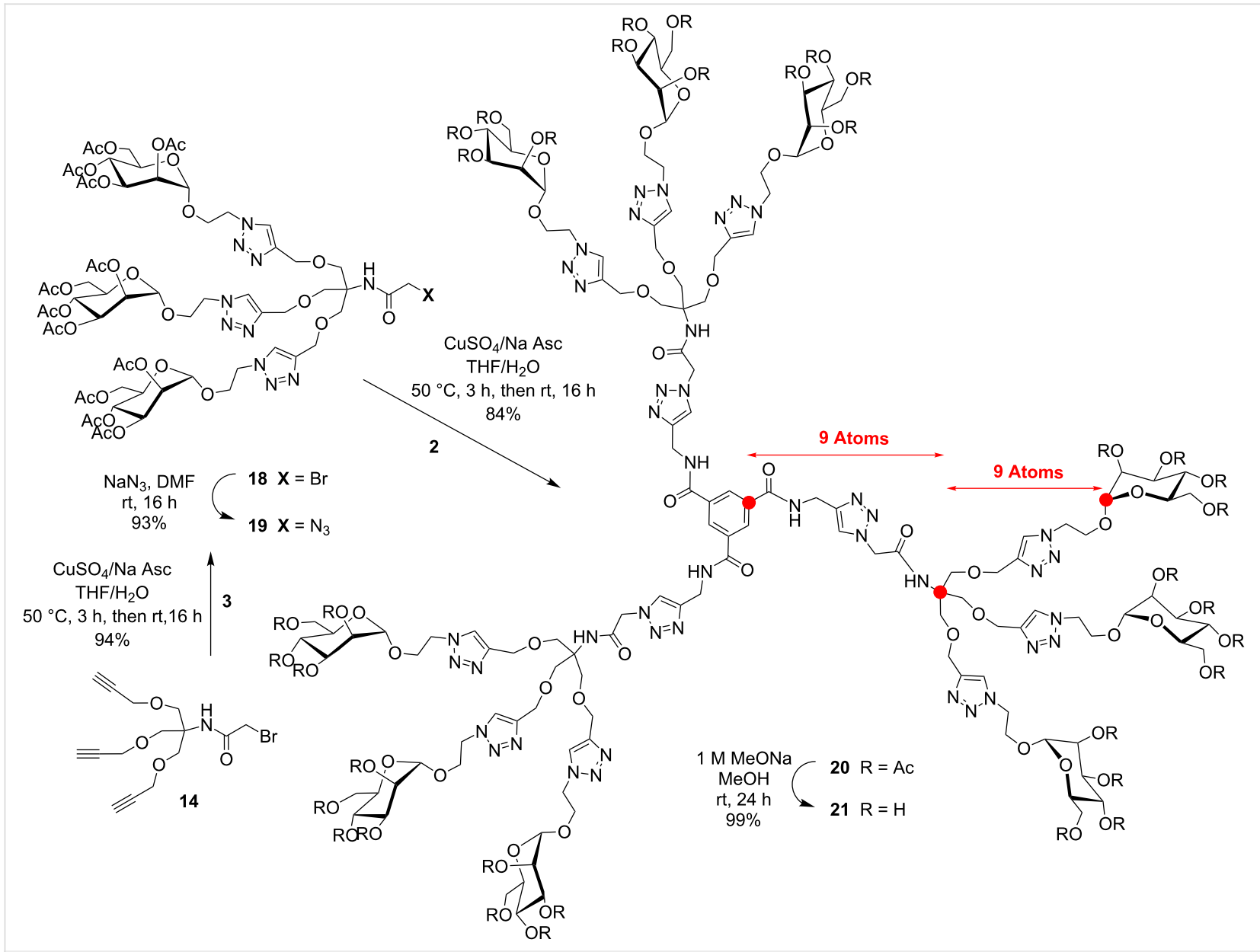

Scheme 4: Convergent synthesis of further "extended" 9-mer 21 using mannosylated bromoacyl dendron 18 transformed into azide 19 followed by CuAAc coupling to tripropargylated core 2. 


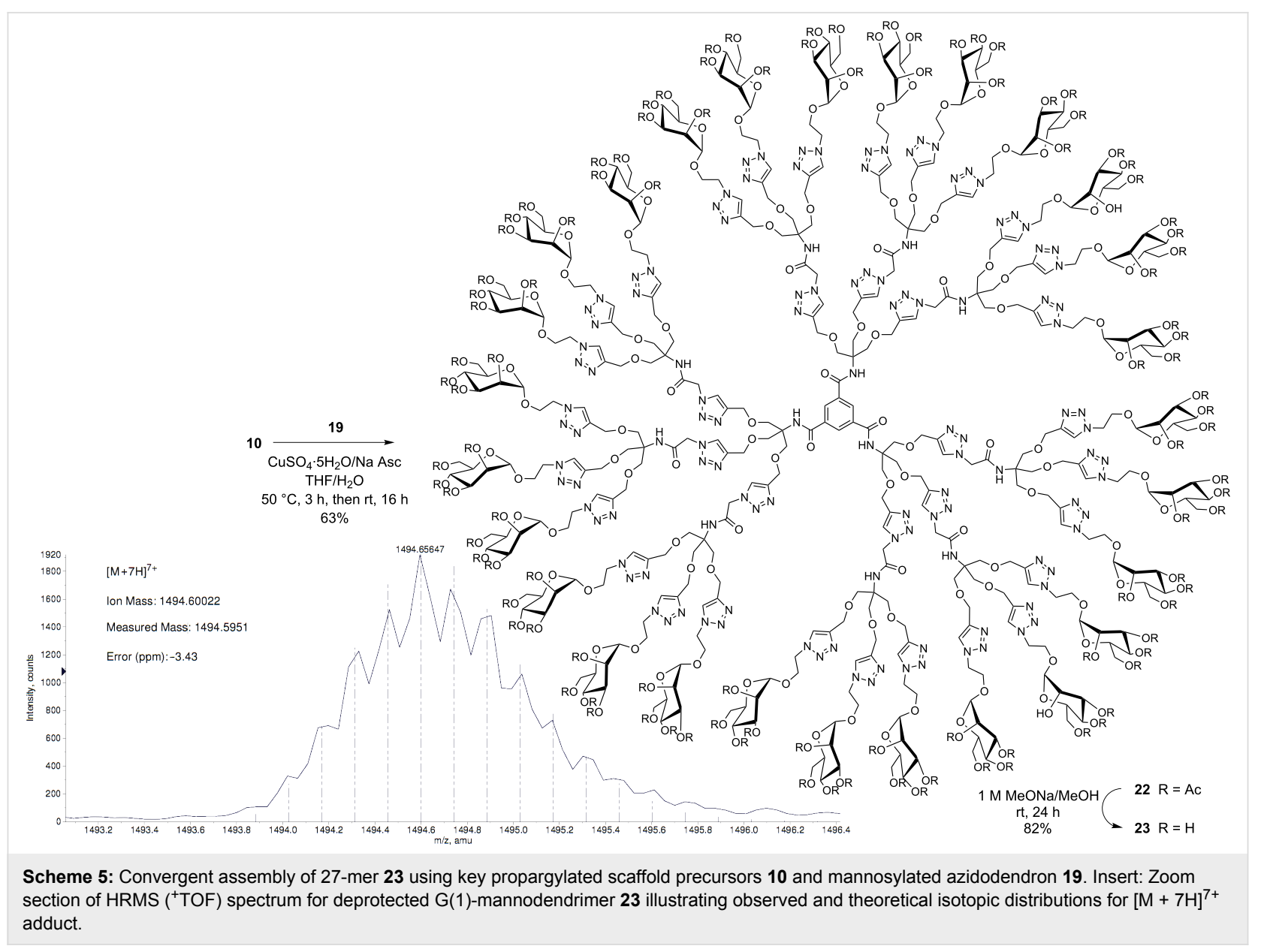

matography, corresponding to an excellent $95 \%$ yield per individual dendron's incorporation. The complete disappearance of propargylic signals in the ${ }^{1} \mathrm{H}$ NMR spectrum supported complete conversion. Note that working with peracetylated sugar precursors allows less tedious purification practices as opposed to working with unprotected sugars which often necessitate purification by cumbersome dialysis followed by HPLC treatment. Here again, the complete structural integrity of the final product can be readily confirmed from its characteristic spectral identification. Ultimately, dendrimer $\mathbf{2 3}$ was deprotected under the usual Zemplén conditions in $82 \%$ yield. Once again, all the relative integrations for each proton presented on the surface were in perfect agreement with those of the middle and internal regions. Interestingly, high resolution mass spectrometry $\left({ }^{+} \mathrm{TOF}\right.$ technique) resulted in the formation of multicharged adducts that matched the expected theoretical patterns, especially the one corresponding to $[\mathrm{M}+7 \mathrm{H}]^{7+}$, as illustrated in Scheme 5 (insert).

\section{NMR diffusion studies}

To accurately estimate the various structural factors involved in the intricate binding interactions between our synthetic multi- meric mannosides and ConA, we determined their relative diffusivity measurements by NMR spectroscopy. In fact, diffusion NMR spectroscopy has recently become a method of choice to access information about sizes and shapes of macromolecular species by measuring their diffusion coefficients in a given solvent [17,37]. The size of nonavalent compounds $\mathbf{1 2}$, $\mathbf{1 7}$, and 21, and more particularly their solvodynamic radii, was thus estimated with the help of pulsed-field-gradient stimulated echo (PFG-STE) NMR experiments using bipolar pulse pairslongitudinal-eddy-current delay (BPP-LED) in $\mathrm{D}_{2} \mathrm{O}$ at $25^{\circ} \mathrm{C}$. Stimulated echoes were used since they avoid signal attenuation due to transverse relaxation while bipolar gradient pulses reduce gradient artefacts [38]. The diffusion rates $(D)$ were calculated from the decay of the signal intensity of the common H-5 proton $(\delta=2.98 \mathrm{ppm})$ located on each epitope with increasing field gradient strength (Figure 1a). In all cases, monoexponential behavior was observed (Figure 1b), which was manifested as a linear decay of the logarithm of the signal intensity as a function of the gradient strength. This behavior is consistent with a spherical and unimolecular character of the glycodendrimers, confirming the absence of aggregation phenomena in aqueous solution under the working concentra- 

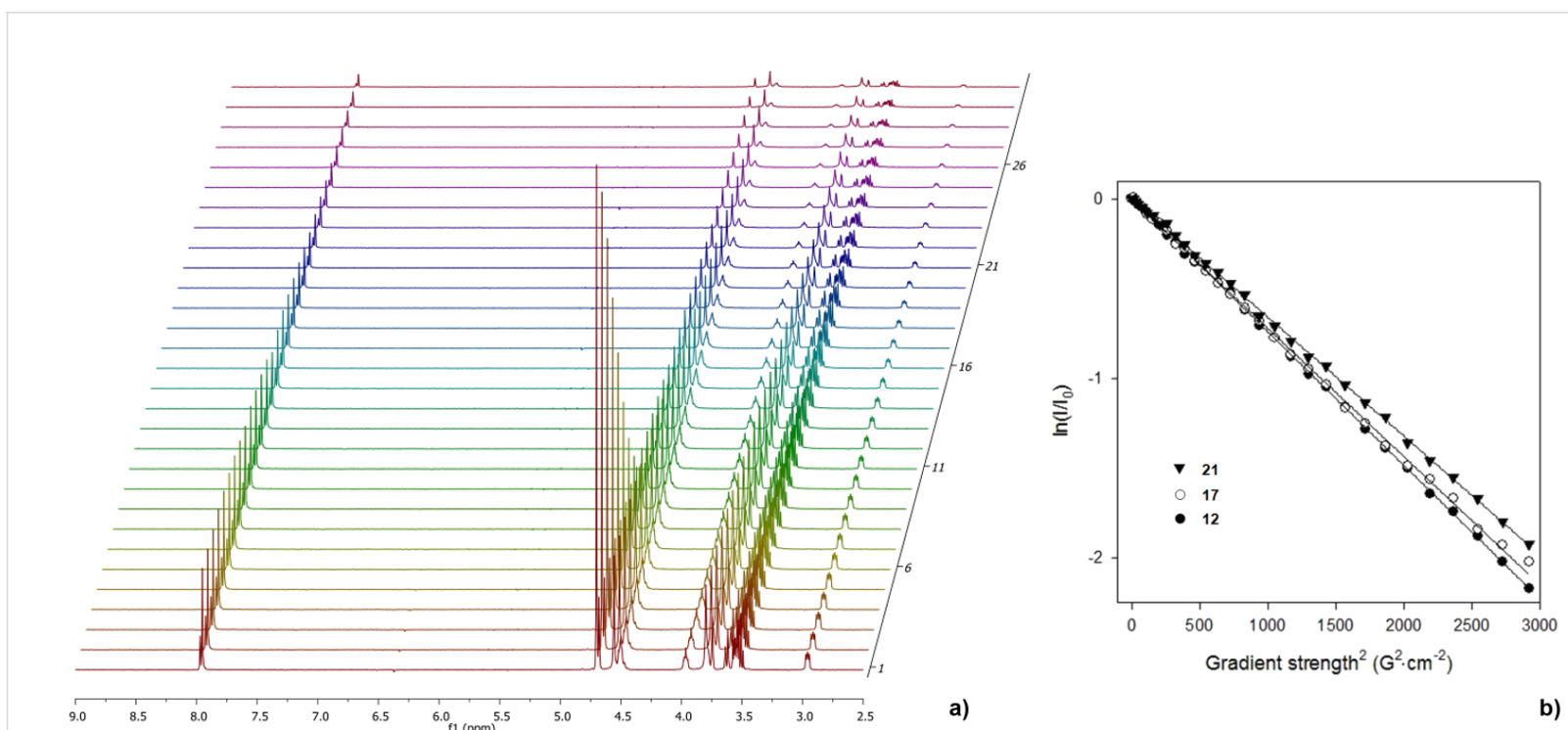

b)

Figure 1: a) Decay of ${ }^{1} \mathrm{H}$ signal for the nonavalent mannosylated compound 12 in $\mathrm{D}_{2} \mathrm{O}$ during the PFGSTE experiment. The gradient strength is increased linearly between 1.8 and $\left.54.2 \mathrm{G} \cdot \mathrm{cm}^{-1} ; \mathrm{b}\right)$ characteristic echo decays of the $\mathrm{H}-5$ resonances $(\delta=2.98 \mathrm{ppm})$ as a function of squared gradient strength located in 12 (full circles) and 21 (full triangles) with $\delta=4 \mathrm{~ms}$ and $\Delta=50 \mathrm{~ms}(\Delta=40 \mathrm{~ms}$ for 17 (circles)). Notably, such linear behavior was also obtained for the decay of the signal intensities of other protons located either in internal regions of the conjugates on aromatic or branching sections, or in the peripheral saccharidic belt (results not shown).

tions. The corresponding solvodynamic diameters $\left(d_{\mathrm{s}}=2 \times r_{\mathrm{s}}\right)$ can be calculated using the Stokes-Einstein equation and the viscosity of pure $\mathrm{D}_{2} \mathrm{O}$ (Table 1 ).

As expected, nonavalent conjugates 12, 17, and 21 presented solvodynamic diameters in the range of roughly $3 \mathrm{~nm}$ when considering the decay of distinctive and common H-5 signals. These values remained consistent with similar congeners described earlier and harboring different epitopes [17]. The variation of the complexity of anchoring functionalities in the middle region with the incorporation of amide functions and triazole groups is responsible for a diameter enhancement for $\mathbf{2 1}$ when compared with $\mathbf{1 2}$, as expected. On the other hand, rather counter-intuitive tendencies were observed since the apparently slightly extended structure $\mathbf{1 7}$ was measured as the smallest molecule of the family in water. A specific spatial arrangement of the dendrons that emanate from 1,3,5-O-alkylations on the aromatic core in $\mathbf{1 7}$, compared to the one generated in BTAscentered structures $\mathbf{1 2}$ and 21, could explain this observation. Also, these discrepancies might result from the general amphiphilic behavior of this kind of macromolecules [39]. In fact, these glycoclusters shared common structural factors with hydrophilic peripheral moieties and an aromatic central core but the introduction of distinct functionalized linkers may change the overall hydrophobic/hydrophilic balances of the structures. As such, they could engage supplementary intramolecular hydrogen bonding or hydrophobic interactions that could mediate their three-dimensional arrangement in aqueous media. Moreover, it is also reported that the relative spatial distribution of the branches around the $\mathrm{C}=\mathrm{O}$-centered BTAs strongly depends on the nature of the substituents [40]. This hypothesis can partly explain the discrepancy observed for the calculated

Table 1: Determination of diffusion data and solvodynamic diameters of nonavalent conjugates 12, 17 , and 21 by diffusion NMR experiments.

\begin{tabular}{cccc} 
Entry & Compound & $D\left[\times 10^{-10} \mathrm{~m}^{2} \mathrm{~s}^{-1}\right]^{\mathrm{a}, \mathrm{b}, \mathrm{c}}$ & Solvodynamic diameter $\left[d_{\mathrm{s}}, \mathrm{nm}\right]^{\mathrm{d}}$ \\
\hline 1 & $\mathbf{1 2}$ & 1.33 & $3.0(2.9)$ \\
2 & 17 & 1.62 & $2.5(2.3)$ \\
3 & $\mathbf{2 1}$ & 1.17 & $3.4(2.9)$ \\
\hline
\end{tabular}

asee general procedures and Supporting Information File 1 for extraction of the diffusion rate and calibration of the gradient strength. $D$ was determined from the decay of the $\mathrm{H}-5$ resonance $(\delta=2.98 \mathrm{ppm})$. ${ }^{b}$ Viscosity of $\mathrm{D}_{2} \mathrm{O}$ at $25^{\circ} \mathrm{C}: \eta \mathrm{D}_{2} \mathrm{O}=1.097 \times 10^{-3} \mathrm{~Pa}$ s. ${ }^{\mathrm{c}} \mathrm{The}$ error associated with the measurement was estimated from repeated calculations of the diffusion coefficients to be below $10 \%$. dResults in parentheses correspond to the average value calculated from the decays of 4 or 5 different proton signals. 
diameter of $\mathbf{2 1}$ (Table 1, entry 3). In fact, diffusion data for $\mathbf{2 1}$ ranged from $1.61 \times 10^{-10} \mathrm{~m}^{2} \mathrm{~s}^{-1}$ for central $\mathrm{C} H_{\text {ar }}$ to $1.17 \times 10^{-10} \mathrm{~m}^{2} \mathrm{~s}^{-1}$ for $\mathrm{H}-5$, indicating a heterogeneity in diffusivity depending on the proton location within the same molecule. As a consequence, the calculated $d_{\mathrm{s}}$ value based on the utilization of an average value of diffusion data $(D)$ extracted from signal decays of distinct protons located at different levels in the molecule differ from that obtained with the decay of peripheral H-5 signal only. This heterogeneity was less pronounced for $\mathbf{1 7}$ and absent for $\mathbf{1 2}$ that presented consistent values of $D$ ranging from 1.51 to $1.33 \times 10^{-10} \mathrm{~m}^{2} \mathrm{~s}^{-1}$ for protons in the core or the periphery. Interestingly, calculation of the extended conformation (MM2, Chem3D) of the linkers in 12, 17, and 21 showed lengths of 14.8, 17.1, and $21.8 \AA$, respectively.

\section{Conclusion}

The syntheses of three related families of mannosylated glycoclusters and glycodendrimers were efficiently accomplished around a benzene core and using the CuAAc methods now routinely used in this field $[9,41,42]$. The targeted compounds were based on trimesic acid scaffold which is known to properly expose the surface sugar groups to tetrameric lectins such as ConA [43] and the LecA lectin from Pseudomonas aeruginosa [17]. With these closely related families of mannosylated dendrimers in hand, together with their known relative size in solution, we are now well positioned to evaluate their binding behavior against their cognate proteins and this work will be published in due course [44].

The study of subtle structural variations and the nature of anchoring functions, as observed in diffusivity experiments, could represent a first step towards rational interpretation to explain the differential kinetic behavior within a closely related family of glycoclusters.

\section{Experimental \\ General remarks}

All reactions in organic medium were performed in standard oven-dried glassware under an inert atmosphere of nitrogen using freshly distilled solvents. $\mathrm{CH}_{2} \mathrm{Cl}_{2}$ was distilled from $\mathrm{CaH}_{2}$ and DMF from ninhydrin, and kept over molecular sieves. Solvents and reagents were deoxygenated when necessary by purging with nitrogen. Water used for lyophilization of final dendrimers was nanopure grade, purified through Barnstead NANOPure II Filter with Barnstead MegOhm-CM Sybron meter. All reagents were used as supplied without prior purification unless otherwise stated, and obtained from SigmaAldrich Chemical Co. Ltd. Reactions were monitored by analytical thin-layer chromatography using silica gel 60 F254 precoated plates (E. Merck) and compounds were visualized by
$254 \mathrm{~nm}$ light, a mixture of iodine/silica gel and/or mixture of ceric ammonium molybdate solution $\left(100 \mathrm{~mL} \mathrm{H}_{2} \mathrm{SO}_{4}, 900 \mathrm{~mL}\right.$ $\left.\mathrm{H}_{2} \mathrm{O}, 25 \mathrm{~g}\left(\mathrm{NH}_{4}\right)_{6} \mathrm{Mo}_{7} \mathrm{O}_{24} \mathrm{H}_{2} \mathrm{O}, 10 \mathrm{~g} \mathrm{Ce}\left(\mathrm{SO}_{4}\right)_{2}\right)$ and subsequent development by gentle warming with a heat-gun. Purifications were performed by flash column chromatography using silica gel from Silicycle ( $60 \AA, 40-63 \mu \mathrm{m})$ with the indicated eluent.

\section{NMR, IR, and MS spectroscopy}

${ }^{1} \mathrm{H}$ NMR and ${ }^{13} \mathrm{C}$ NMR spectra were recorded at 300 or $600 \mathrm{MHz}$ and 75 or $150 \mathrm{MHz}$, respectively, on a Bruker spectrometer $(300 \mathrm{MHz})$ and Varian spectrometer $(600 \mathrm{MHz})$. All NMR spectra were measured at $25{ }^{\circ} \mathrm{C}$ in indicated deuterated solvents. Proton and carbon chemical shifts $(\delta)$ are reported in ppm and coupling constants $(J)$ are reported in Hertz $(\mathrm{Hz})$. The resonance multiplicity in the ${ }^{1} \mathrm{H}$ NMR spectra are described as "s" (singlet), "d" (doublet), "t" (triplet), and "m" (multiplet) and broad resonances are indicated by "br". Residual protic solvent of $\mathrm{CDCl}_{3}\left({ }^{1} \mathrm{H}, \delta 7.27 \mathrm{ppm} ;{ }^{13} \mathrm{C}, \delta 77.0 \mathrm{ppm}\right.$ (central resonance of the triplet)), $\mathrm{D}_{2} \mathrm{O}\left({ }^{1} \mathrm{H}, \delta 4.79 \mathrm{ppm}\right.$ and $30.89 \mathrm{ppm}$ for $\mathrm{CH}_{3}$ of acetone for ${ }^{13} \mathrm{C}$ spectra of de- $O$-acetylated compounds), MeOD $\left({ }^{1} \mathrm{H}, \delta 3.31 \mathrm{ppm}\right.$ and $\left.{ }^{13} \mathrm{C}, \delta 49.0 \mathrm{ppm}\right) .2 \mathrm{D}$ Homonuclear correlation ${ }^{1} \mathrm{H}-{ }^{1} \mathrm{H}$ COSY together with $2 \mathrm{D}$ heteronuclear correlation ${ }^{1} \mathrm{H}-{ }^{13} \mathrm{C}$ HSQC experiments were used to confirm NMR peak assignments.

Fourier transform infrared (FTIR) spectra were obtained with Thermo-scientific, Nicolet model 6700 equipped with ATR. The absorptions are given in wavenumbers $\left(\mathrm{cm}^{-1}\right)$. The intensity of the bands is described as s (strong), $\mathrm{m}$ (medium) or w (weak). Melting points were measured on a Electrothermal MEL-TEMP apparatus and are uncorrected.

Accurate mass measurements (HRMS) were performed on a LC-MSD-ToF instrument from Agilent Technologies in positive electrospray mode. Low-resolution mass spectra were performed on the same apparatus or on a LCQ Advantage ion trap instrument from Thermo Fisher Scientific in positive electrospray mode (Mass Spectrometry Laboratory (Université de Montréal), or Plateforme analytique pour molécules organiques (Université du Québec à Montréal), Québec, Canada). Either protonated molecular ions $[\mathrm{M}+n \mathrm{H}]^{n+}$ or adducts $[\mathrm{M}+n \mathrm{X}]^{n+}$ $\left(\mathrm{X}=\mathrm{Na}, \mathrm{K}, \mathrm{NH}_{4}\right)$ were used for empirical formula confirmation.

NMR diffusion measurements were performed at $25^{\circ} \mathrm{C}$ on a Varian Inova Unity 600 spectrometer (Varian, Walnut Creek, CA, USA) operating at a frequency of $599.95 \mathrm{MHz}$ for ${ }^{1} \mathrm{H}$ using a $5 \mathrm{~mm}$ broadband $z$-gradient temperature-regulated probe. The temperature was calibrated with 1,2-ethanediol according to a standard procedure [38]. The diffusion experiment employed a 
bipolar pulse-field gradients stimulated echo sequence as proposed by $\mathrm{Wu}$ et al [45]. The gradient pulse duration $\delta$ was $4 \mathrm{~ms}$ and the diffusion times $(\Delta)$ were 40 to $50 \mathrm{~ms}$ to ensure that the echo intensities were attenuated by at least $80 \%$. A complete attenuation curve was obtained by measuring 30 gradient strengths, which were linearly incremented between 1.8 and $54.2 \mathrm{Gcm}^{-1}$. Hard $90^{\circ}{ }^{1} \mathrm{H}$ pulses of $15 \mu$ s were used and $36 \mathrm{k}$ data points were recorded with 16 scans acquired for each gradient's strength. A recycle delay of $3.0 \mathrm{~s}$ was used. The gradient strength was calibrated by back calculation of the coil constant from diffusion experiments on $\mathrm{H}_{2} \mathrm{O}$ traces in $\mathrm{D}_{2} \mathrm{O}$ $\left(D=1.90 \times 10^{-9} \mathrm{~m}^{2} \mathrm{~s}^{-1}\right)[46]$.

Diffusion rates were extracted from the slope of the straight lines obtained by plotting $\ln (I)$ against the gradient-pulse power squared according to the following equation: $\ln (I)=$ $-D \gamma^{2} G^{2} \delta^{2}(\Delta-\delta / 3-\tau / 2)+\ln \left(I_{0}\right)$ where $I$ is the relative intensity of a chosen resonance $\left(I=I_{0} \exp -\left[D \gamma^{2} G^{2} \delta^{2}(\Delta-\delta / 3-\right.\right.$ $\tau / 2)]), G=$ gradient strength $(T / \mathrm{m}), \gamma=$ proton gyromagnetic ratio, $D=$ diffusion rate $\left(\mathrm{m}^{2} \mathrm{~s}^{-1}\right), \delta=$ gradient duration, $\Delta=$ diffusion delay, and $\tau=$ pulse length for bipolar pulses. All diffusion spectra were processed in Mat NMR [47].

\section{Glycodendrimer synthesis \\ Procedure A: multiple CuAAc couplings on polypropargylated cores}

To a solution of polypropargylated core (1.00 equiv) and complementary azido synthon (1.25 equiv/propargyl) in a THF/ $\mathrm{H}_{2} \mathrm{O}$ mixture (1:1) were added sodium ascorbate ( 0.30 equiv/ propargyl) and $\mathrm{CuSO}_{4} \cdot 5 \mathrm{H}_{2} \mathrm{O}(0.30$ equiv/propargyl). The reaction mixture was stirred at $50{ }^{\circ} \mathrm{C}$ for $3 \mathrm{~h}$ then at room temperature for an additional $16 \mathrm{~h}$ period. Ethyl acetate $(10 \mathrm{~mL})$ was added and the resulting solution was poured in a separatory funnel containing $25 \mathrm{~mL}$ of EtOAc and $30 \mathrm{~mL}$ of a saturated aqueous solution of $\mathrm{NH}_{4} \mathrm{Cl}$. Organics were washed with $(2 \times 25 \mathrm{~mL})$ of saturated $\mathrm{NH}_{4} \mathrm{Cl}_{\mathrm{aq}}$, water $(2 \times 20 \mathrm{~mL})$ and brine $(1 \times 10 \mathrm{~mL})$. The organic phase was then dried over $\mathrm{MgSO}_{4}$ and concentrated under reduced pressure. Column chromatography on silica (DCM/MeOH 100:0 to 90:10) afforded the desired glycocluster.

\section{Procedure B: Zemplén de-O-acetylation procedure for insoluble hydroxylated derivatives}

The acetylated compound was dissolved in anhydrous $\mathrm{MeOH}$ and a solution of sodium methoxide $(1 \mathrm{M}$ in $\mathrm{MeOH}, 5 \mu \mathrm{L}$ every 20 min until precipitation) was added. An additional $100 \mu \mathrm{L}$ was then injected and the heterogeneous reaction mixture was stirred at room temperature for $24 \mathrm{~h}$. The solvent was then removed with a Pasteur pipette and a mixture of anhydrous $\mathrm{MeOH} / \mathrm{DCM}$ (4:1, $5 \mathrm{~mL}$ ) was added to the residual white foam. A vigorous agitation is maintained for an additional $15 \mathrm{~min}$ period. After removal of the solvents with a Pasteur pipette, the residue was dissolved in $\mathrm{H}_{2} \mathrm{O}(3 \mathrm{~mL})$, and the $\mathrm{pH}$ was adjusted to 7 by the addition of ion-exchange resin (Amberlite IR 120 $\mathrm{H}^{+}$). After filtration, the solvent was removed under vacuum with a rotary evaporator and lyophilized to yield the fully deprotected glycocluster.

Synthesis of peracetylated trivalent derivative 8: To a solution of triazido core $6(50.0 \mathrm{mg}, 109 \mu \mathrm{mol}, 1.00$ equiv $)$ and mannoside 7 ( $158 \mathrm{mg}, 409 \mu \mathrm{mol}, 3.75$ equiv) in a $\mathrm{THF} / \mathrm{H}_{2} \mathrm{O}$ mixture $(1: 1,6 \mathrm{~mL})$ were added sodium ascorbate $(19.4 \mathrm{mg}$, $98.1 \mu \mathrm{mol}, 0.90$ equiv) and $\mathrm{CuSO}_{4} \cdot 5 \mathrm{H}_{2} \mathrm{O}(24.5 \mathrm{mg}, 98.1 \mu \mathrm{mol}$, 0.90 equiv). The reaction mixture was stirred at $50{ }^{\circ} \mathrm{C}$ for $3 \mathrm{~h}$ then at room temperature for an additional $16 \mathrm{~h}$ period. Ethyl acetate $(10 \mathrm{~mL})$ was added and the resulting solution was poured in a separatory funnel containing $35 \mathrm{~mL}$ of EtOAc and $30 \mathrm{~mL}$ of a saturated aqueous solution of $\mathrm{NH}_{4} \mathrm{Cl}$. Organics were washed with $(2 \times 25 \mathrm{~mL})$ of saturated $\mathrm{NH}_{4} \mathrm{Cl}_{\mathrm{aq}}$, water $(2 \times 20 \mathrm{~mL})$ and brine $(1 \times 10 \mathrm{~mL})$. The organic phase was then dried over $\mathrm{MgSO}_{4}$ and concentrated under reduced pressure. Column chromatography on silica (DCM/MeOH 98:2 to 94:6) afforded the desired compound 8 (138 $\mathrm{mg}, 86.0 \mu \mathrm{mol}, 79 \%)$ as a viscous oil. $R_{\mathrm{f}} 0.34(95: 5 \mathrm{DCM} / \mathrm{MeOH}) ;{ }^{1} \mathrm{H} \mathrm{NMR}(600 \mathrm{MHz}$, $\left.\mathrm{CDCl}_{3}\right) \delta(\mathrm{ppm}) 8.27\left(\mathrm{~s}, 3 \mathrm{H}, \mathrm{CH}_{\mathrm{ar}}\right), 7.79\left(\mathrm{~s}, 3 \mathrm{H}, \mathrm{CH}_{\text {triazole }}\right)$, $7.72(\mathrm{t}, J=5.3 \mathrm{~Hz}, 3 \mathrm{H}, \mathrm{N} H), 5.29-5.19\left(\mathrm{~m}, 9 \mathrm{H}, H_{2}, H_{3}, H_{4}\right)$, $4.92\left(\mathrm{~s}_{\mathrm{app}}, 3 \mathrm{H}, H_{1}\right), 4.77-4.62\left(2 \times \mathrm{d}, J=12.4 \mathrm{~Hz}, 6 \mathrm{H}, \mathrm{OCH}_{2}\right)$, $4.54\left(\mathrm{t}, J=6.4 \mathrm{~Hz}, 6 \mathrm{H}, \mathrm{N}_{\text {triazole }} \mathrm{CH}_{2}\right), 4.28(\mathrm{dd}, J=12.4 \mathrm{~Hz}, J=$ $\left.5.4 \mathrm{~Hz}, 3 \mathrm{H}, H_{6 \mathrm{~b}}\right), 4.11-4.03\left(\mathrm{~m}, 6 \mathrm{H}, H_{5}+H_{6 \mathrm{a}}\right), 3.55(\mathrm{~m}, 6 \mathrm{H}$, $\left.\mathrm{NHCH}_{2}\right), 2.28\left(\mathrm{~m}, 6 \mathrm{H}, \mathrm{CH}_{2} \mathrm{CH}_{2} \mathrm{CH}_{2}\right), 2.12,2.10,2.02,1.96$ $\left(4 \mathrm{~s}, 36 \mathrm{H}, \mathrm{COCH}_{3}\right) ;{ }^{13} \mathrm{C}\left\{{ }^{1} \mathrm{H}\right\} \mathrm{NMR}\left(150 \mathrm{MHz}, \mathrm{CDCl}_{3}\right) \delta(\mathrm{ppm})$ 170.8, 170.1, 170.0, $169.7\left(\mathrm{COCH}_{3}\right), 166.1(\mathrm{CONH}), 143.5$ $\left(C_{\text {triazole }}\right), 134.9\left(C_{\text {arom }}\right), 128.5\left(C \mathrm{H}_{\text {arom }}\right), 123.9\left(C \mathrm{H}_{\text {triazole }}\right)$, $96.7\left(C_{1}\right), 69.3\left(C_{2}\right), 69.0\left(C_{3}\right), 68.7\left(C_{5}\right), 65.9\left(C_{6}\right), 62.3\left(C_{4}\right)$, $60.7\left(\mathrm{OCH}_{2}\right), 48.3\left(\mathrm{CH}_{2} \mathrm{~N}_{\text {triazole }}\right), 37.5\left(\mathrm{NHCH}_{2}\right), 29.9$ $\left(\mathrm{CH}_{2} \mathrm{CH}_{2} \mathrm{CH}_{2}\right), 20.9,20.8,20.7,20.7\left(\mathrm{COCH}_{3}\right)$; MS ( ${ }^{+} \mathrm{TOF}-$ $\mathrm{MS}, m / z):[\mathrm{M}+\mathrm{H}]^{+}$calculated for $\mathrm{C}_{69} \mathrm{H}_{90} \mathrm{~N}_{12} \mathrm{O}_{33}, 1615.6$; found, 1615.6.

Synthesis of nonapropargylated core 15: To a solution of phloroglucinol (13, $10.0 \mathrm{mg}, 79.3 \mu \mathrm{mol}, 1.00$ equiv) in anhydrous DMF ( $3 \mathrm{~mL}$ ) was added under nitrogen anhydrous $\mathrm{K}_{2} \mathrm{CO}_{3}$ (previously heated at $250{ }^{\circ} \mathrm{C}$ under vaccum, $39.5 \mathrm{mg}$, $285 \mu \mathrm{mol}, 3.60$ equiv). After $10 \mathrm{~min}$ of vigorous stirring, tripropargylated synthon 14 (93.0 mg, $285 \mu \mathrm{mol}, 3.60$ equiv) was added into the solution under inert atmosphere and the reaction mixture was allowed to stir at $65^{\circ} \mathrm{C}$ for $39 \mathrm{~h}$. In the end, the dark-brown heterogeneous reaction was poured in $30 \mathrm{~mL}$ of EtOAc and organics were washed with a saturated aqueous solution of $\mathrm{NH}_{4} \mathrm{Cl}(2 \times 30 \mathrm{~mL})$ then water $(2 \times 20 \mathrm{~mL})$ and brine $(10 \mathrm{~mL})$. The organic phase was then dried over $\mathrm{MgSO}_{4}$ and concentrated under reduced pressure. Column chro- 
matography on silica (EtOAc/hexane 40:60 to 50:50) afforded the desired compound $\mathbf{1 5}(32.0 \mathrm{mg}, 33.8 \mu \mathrm{mol}, 43 \%)$ as a colorless oil. $R_{\mathrm{f}} 0.27$ (1:1 EtOAc/hexane); ${ }^{1} \mathrm{H}$ NMR $(300 \mathrm{MHz}$, $\left.\mathrm{CDCl}_{3}\right) \delta(\mathrm{ppm}) 6.85(\mathrm{~s}, 3 \mathrm{H}, \mathrm{NH}), 6.17\left(\mathrm{~s}, 3 \mathrm{H}, \mathrm{CH}_{\mathrm{ar}}\right), 4.36(\mathrm{~s}$, $\left.6 \mathrm{H}, \mathrm{OCH}_{2} \mathrm{CONH}\right), 4.16\left(\mathrm{~m}, 18 \mathrm{H}, \mathrm{OCH}_{2} \mathrm{C} \equiv \mathrm{CH}\right), 3.87$ (br s, $\left.18 \mathrm{H}, \mathrm{HNC}_{\mathrm{q}} \mathrm{CH}_{2} \mathrm{O}\right), 2.48\left(\mathrm{~m}, 9 \mathrm{H}, \mathrm{OCH}_{2} \mathrm{C} \equiv \mathrm{CH}\right) ;{ }^{13} \mathrm{C}\left\{{ }^{1} \mathrm{H}\right\} \mathrm{NMR}$ $\left(75 \mathrm{MHz}, \mathrm{CDCl}_{3}\right) \delta(\mathrm{ppm}) 167.3(\mathrm{CONH}), 159.0\left(\mathrm{C}_{\mathrm{ar}} \mathrm{OCH}_{2}\right)$, $95.8\left(\mathrm{CH}_{\mathrm{ar}}\right), 79.4\left(\mathrm{OCH}_{2} \mathrm{C} \equiv \mathrm{CH}\right), 74.9\left(\mathrm{OCH}_{2} \mathrm{C} \equiv \mathrm{CH}\right), 68.3$ $\left(\mathrm{HNC}_{\mathrm{q}} \mathrm{CH}_{2} \mathrm{O}\right), 67.5\left(\mathrm{OCH}_{2} \mathrm{CONH}\right), 59.2\left(C_{\mathrm{q}}\right), 58.6$ $\left(\mathrm{OCH}_{2} \mathrm{C} \equiv \mathrm{CH}\right)$; HRMS $\left({ }^{+}\right.$TOF-HRMS, $\left.m / z\right):[\mathrm{M}+\mathrm{H}]^{+}$calculated for $\mathrm{C}_{51} \mathrm{H}_{57} \mathrm{~N}_{3} \mathrm{O}_{15}, 952.3862$; found, $952.3843(\Delta=-2.10$ ppm); $[\mathrm{M}+\mathrm{Na}]^{+}$: calculated for 974.3682 ; found, $974.3662(\Delta$ $=-2.05 \mathrm{ppm})$.

Synthesis of bromoacylated dendron 18: To a solution of tripropargylated synthon 14 ( $140.0 \mathrm{mg}, 393.0 \mu \mathrm{mol}, 1.00$ equiv) and mannoside 3 (616 mg, $1.48 \mathrm{mmol}, 3.75$ equiv) in a THF/ $\mathrm{H}_{2} \mathrm{O}$ mixture $(1: 1,6 \mathrm{~mL})$ were added sodium ascorbate (70.0 mg, $354 \mu \mathrm{mol}, 0.90$ equiv) and $\mathrm{CuSO}_{4} \cdot 5 \mathrm{H}_{2} \mathrm{O}(88.4 \mathrm{mg}$, $354 \mu \mathrm{mol}, 0.90$ equiv). The reaction mixture was stirred at $50{ }^{\circ} \mathrm{C}$ for $3 \mathrm{~h}$ then at room temperature for an additional $16 \mathrm{~h}$ period. Ethyl acetate $(20 \mathrm{~mL})$ was added and the resulting solution was poured in a separatory funnel containing $40 \mathrm{~mL}$ of EtOAc and $30 \mathrm{~mL}$ of a saturated aqueous solution of $\mathrm{NH}_{4} \mathrm{Cl}$. Organics were washed with $2 \times 35 \mathrm{~mL}$ of saturated $\mathrm{NH}_{4} \mathrm{Cl}_{\mathrm{aq}}$, water $(2 \times 30 \mathrm{~mL})$ and brine $(20 \mathrm{~mL})$. The organic phase was then dried over $\mathrm{MgSO}_{4}$ and concentrated under reduced pressure. Column chromatography on silica (DCM/MeOH 99:1 to 96:4) afforded the desired compound 18 (594 mg, $369.4 \mu \mathrm{mol}$, $94 \%)$ as a white solid. $R_{\mathrm{f}} 0.47(94: 6 \mathrm{DCM} / \mathrm{MeOH}) ; \mathrm{mp}$ $68-72{ }^{\circ} \mathrm{C}$ (not corrected); ${ }^{1} \mathrm{H}$ NMR $\left(300 \mathrm{MHz}, \mathrm{CDCl}_{3}\right) \delta$ (ppm) 7.68 (br s, $\left.3 \mathrm{H}, \mathrm{C} H_{\text {triazole }}\right), 6.89$ (br s, $\left.1 \mathrm{H}, \mathrm{NH}\right), 5.24-5.18(\mathrm{~m}$, $\left.9 \mathrm{H}, H_{2}, H_{3}, H_{4}\right), 4.80$ (d, $\left.J=1.3 \mathrm{~Hz}, 1 \mathrm{H}, H_{1}\right), 4.61-4.58$ (br s, $\left.12 \mathrm{H}, \mathrm{OCH}_{2} \mathrm{C}_{\text {triazole }}+\mathrm{N}_{\text {triazole }} \mathrm{CH}_{2}\right), 4.17-4.00(\mathrm{~m}, 11 \mathrm{H}$, $\left.\mathrm{OCH}_{2} \mathrm{CH}_{2}+H_{6 \mathrm{a}}+\mathrm{BrCH}_{2} \mathrm{CONH}\right), 3.94-3.78\left(\mathrm{~m}, 9 \mathrm{H}, \mathrm{H}_{6 \mathrm{~b}}+\right.$ $\left.\mathrm{NHC}_{\mathrm{q}} \mathrm{CH}_{2} \mathrm{O}\right), 3.60\left(\mathrm{~m}, 3 \mathrm{H}, H_{5}\right), 2.12,2.08,2.03,1.98(4 \mathrm{~s}, 36 \mathrm{H}$, $\left.\mathrm{COCH}_{3}\right) ;{ }^{13} \mathrm{C}\left\{{ }^{1} \mathrm{H}\right\}$ NMR $\left(75 \mathrm{MHz}, \mathrm{CDCl}_{3}\right) \delta(\mathrm{ppm})$ 170.5, $169.9,169.9,169.5,\left(\mathrm{COCH}_{3}\right), 165.6(\mathrm{CONH}), 145.0\left(C_{\text {triazole }}\right)$, $123.7\left(\mathrm{CH}_{\text {triazole }}\right), 97.4\left(C_{1}\right), 69.1\left(C_{2}\right), 68.9\left(C_{3}\right), 68.8\left(C_{5}\right)$, $68.4\left(\mathrm{NHC}_{\mathrm{q}} \mathrm{CH}_{2} \mathrm{O}\right), 66.2\left(C_{6}\right), 65.6\left(C_{4}\right), 64.6\left(\mathrm{OCH}_{2} \mathrm{C}_{\text {triazole }}\right)$, $62.1\left(\mathrm{OCH}_{2} \mathrm{CH}_{2}\right), 60.2\left(C_{\mathrm{q}}\right), 49.6\left(\mathrm{CH}_{2} \mathrm{~N}_{\text {triazole }}\right), 29.7\left(\mathrm{CH}_{2} \mathrm{Br}\right)$, 20.8, 20.7, 20.6, $20.6\left(\mathrm{COCH}_{3}\right)$; IR $\left(\mathrm{cm}^{-1}\right): 2956,2937,2361$, 2337, 1751, 1734, 1540, 1370, 1218, 1045, 759; HRMS ( ${ }^{+}$TOFHRMS, $m / z):[\mathrm{M}+2 \mathrm{H}]^{2+}$ calculated for $\mathrm{C}_{63} \mathrm{H}_{87} \mathrm{BrN}_{10} \mathrm{O}_{34}$, 804.2358; found, $804.2356(\Delta=-0.18 \mathrm{ppm}) ;[\mathrm{M}+\mathrm{H}]^{+}$calculated for 1607.4642 , found: $1607.4620(\Delta=-1.36 \mathrm{ppm})$; [M + $\mathrm{Na}]^{+}$calculated for 1629.4462 ; found, $1629.4448(\Delta=-0.84$ $\mathrm{ppm})$.

Synthesis of azidoacylated dendron 19: To a stirring solution of brominated trivalent dendron $18(121.0 \mathrm{mg}, 75.2 \mu \mathrm{mol}$,
1.00 equiv) in dry DMF (1.5 mL) was added under a nitrogen atmosphere sodium azide $(7.3 \mathrm{mg}, 112 \mu \mathrm{mol}, 1.50$ equiv). After stirring overnight at room temperature, the solvent was removed under vaccum. Ethyl acetate $(20 \mathrm{~mL})$ was added and the resulting solution was poured in a separatory funnel containing $20 \mathrm{~mL}$ of EtOAc and $30 \mathrm{~mL}$ of a saturated aqueous solution of $\mathrm{NH}_{4} \mathrm{Cl}$. Organics were washed with $2 \times 30 \mathrm{~mL}$ of saturated $\mathrm{NH}_{4} \mathrm{Cl}_{\mathrm{aq}}$, water $(2 \times 30 \mathrm{~mL})$ and brine $(20 \mathrm{~mL})$. The organic phase was then dried over $\mathrm{MgSO}_{4}$ and concentrated under reduced pressure to furnish the desired compound 19 (110 mg, $69.9 \mu \mathrm{mol}, 93 \%)$ as a white solid. $R_{\mathrm{f}} 0.47(94: 6 \mathrm{DCM} / \mathrm{MeOH})$; mp 62-65 ${ }^{\circ} \mathrm{C}$ (not corrected); ${ }^{1} \mathrm{H}$ NMR $\left(300 \mathrm{MHz}, \mathrm{CDCl}_{3}\right) \delta$ (ppm) 7.68 (br s, 3H, CH $\left.H_{\text {triazole }}\right), 6.69$ (br s, $\left.1 \mathrm{H}, \mathrm{NH}\right), 5.27-5.18$ $\left(\mathrm{m}, 9 \mathrm{H}, H_{2}, H_{3}, H_{4}\right), 4.80\left(\mathrm{~d}, J=1.3 \mathrm{~Hz}, 1 \mathrm{H}, H_{1}\right), 4.61-4.58(\mathrm{br}$ $\left.\mathrm{s}, 12 \mathrm{H}, \mathrm{OCH}_{2} \mathrm{C}_{\text {triazole }}+\mathrm{N}_{\text {triazole }} \mathrm{CH}_{2}\right), 4.23-4.00(\mathrm{~m}, 11 \mathrm{H}$, $\left.\mathrm{OCH}_{2} \mathrm{CH}_{2}+\mathrm{H}_{6 \mathrm{a}}+\mathrm{N}_{3} \mathrm{CH}_{2} \mathrm{CONH}\right), 3.90-3.81\left(\mathrm{~m}, 9 \mathrm{H}, \mathrm{H}_{6 \mathrm{~b}}+\right.$ $\left.\mathrm{NHC}_{\mathrm{q}} \mathrm{CH}_{2} \mathrm{O}\right), 3.60\left(\mathrm{~m}, 3 \mathrm{H}, H_{5}\right), 2.12,2.08,2.03,1.98(4 \mathrm{~s}, 36 \mathrm{H}$, $\left.\mathrm{COCH}_{3}\right) ;{ }^{13} \mathrm{C}\left\{{ }^{1} \mathrm{H}\right\} \mathrm{NMR}\left(75 \mathrm{MHz}, \mathrm{CDCl}_{3}\right) \delta(\mathrm{ppm}) 170.4$, $169.9,169.8,169.5,\left(\mathrm{COCH}_{3}\right), 166.7(\mathrm{CONH}), 144.9\left(C_{\text {triazole }}\right)$, $123.7\left(C_{\text {triazole }}\right), 97.4\left(C_{1}\right), 69.0\left(C_{2}\right), 68.8\left(C_{3}\right), 68.8\left(C_{5}\right)$, $68.4\left(\mathrm{NHC}_{\mathrm{q}} \mathrm{CH}_{2} \mathrm{O}\right), 66.1\left(C_{6}\right), 65.6\left(C_{4}\right), 64.5\left(\mathrm{OCH}_{2} \mathrm{C}_{\text {triazole }}\right)$, $62.1\left(\mathrm{OCH}_{2} \mathrm{CH}_{2}\right), 59.9\left(C_{\mathrm{q}}\right), 52.5\left(\mathrm{CH}_{2} \mathrm{~N}_{3}\right), 49.5\left(\mathrm{CH}_{2} \mathrm{~N}_{\text {triazole }}\right)$, 20.7, 20.7, 20.6, $20.6\left(\mathrm{COCH}_{3}\right)$; IR $\left(\mathrm{cm}^{-1}\right)$ : 2934, 2361, 2338, $2107\left(\mathrm{~N}_{3}\right), 1751,1734,1540,1373,1218,1045,761$; HRMS $\left(^{+}\right.$TOF-HRMS, $\left.m / z\right):[\mathrm{M}+\mathrm{H}]^{+}$calculated for $\mathrm{C}_{63} \mathrm{H}_{87} \mathrm{~N}_{13} \mathrm{O}_{34}$, 1570.5551; found, $1570.5543(\Delta=-0.51 \mathrm{ppm}) ;[\mathrm{M}+\mathrm{Na}]^{+}$ calculated for 1592.5371 ; found, $1592.5366(\Delta=-0.31 \mathrm{ppm})$.

Synthesis of peracetylated 27-mer derivative 22: To a solution of nonapropargylated core $\mathbf{1 0}(4.6 \mathrm{mg}, 5.38 \mu \mathrm{mol}$, 1.00 equiv) and trimannosylated dendron $19(95.0 \mathrm{mg}$, $60.5 \mu \mathrm{mol}, 11.25$ equiv) in a $\mathrm{THF} / \mathrm{H}_{2} \mathrm{O}$ mixture $(1: 1,3 \mathrm{~mL})$ were added sodium ascorbate ( $2.9 \mathrm{mg}, 15 \mu \mathrm{mol}, 2.70$ equiv) and $\mathrm{CuSO}_{4} \cdot 5 \mathrm{H}_{2} \mathrm{O}$ ( $3.6 \mathrm{mg}, 15 \mu \mathrm{mol}, 0.90$ equiv). The reaction mixture was stirred at $50{ }^{\circ} \mathrm{C}$ for $3 \mathrm{~h}$ then at room temperature for an additional $16 \mathrm{~h}$ period. Ethyl acetate $(10 \mathrm{~mL})$ was added and the resulting solution was poured in a separatory funnel containing $25 \mathrm{~mL}$ of EtOAc and $30 \mathrm{~mL}$ of a saturated aqueous solution of $\mathrm{NH}_{4} \mathrm{Cl}$. Organics were washed with $2 \times 25 \mathrm{~mL}$ of saturated $\mathrm{NH}_{4} \mathrm{Cl}_{\mathrm{aq}}$, water $(2 \times 20 \mathrm{~mL})$ and brine $(10 \mathrm{~mL})$. The organic phase was then dried over $\mathrm{MgSO}_{4}$ and concentrated under reduced pressure. Column chromatography on silica (DCM/ $\mathrm{MeOH}$ 98:2 to 90:10) afforded the desired compound 22 (50.0 mg, $3.33 \mu \mathrm{mol}, 63 \%)$ as a yellowish oil. $R_{\mathrm{f}} 0.72(90: 10$ $\mathrm{DCM} / \mathrm{MeOH}) ;{ }^{1} \mathrm{H} \mathrm{NMR}\left(600 \mathrm{MHz}, \mathrm{CDCl}_{3}\right) \delta(\mathrm{ppm}) 8.27(\mathrm{~m}$, $\left.3 \mathrm{H}, \mathrm{C} H_{\mathrm{ar}}\right), 7.79\left(\mathrm{~s}, 9 \mathrm{H}, \mathrm{C} H_{\text {int-triazole }}\right), 7.75(\mathrm{~s}, 27 \mathrm{H}$, $\mathrm{C}_{\text {ext-triazole }}$ ), 7.34-7.31 (m, 12H, NH), 5.23-5.18 (m, 81H, $H_{2}$, $\left.H_{3}, H_{4}\right), 5.05$ (br s, $\left.18 \mathrm{H}, \mathrm{N}_{\text {triazole }} \mathrm{CH}_{2} \mathrm{CONH}\right), 4.81\left(\mathrm{~s}_{\text {app }}, 27 \mathrm{H}\right.$, $\left.H_{1}\right), 4.62-4.53\left(\mathrm{~m}, 126 \mathrm{H}, \mathrm{OCH}_{2} \mathrm{C}_{\text {triazole }}+\mathrm{N}_{\text {triazole }} \mathrm{CH}_{2}\right)$, 4.20-3.64 (m, 207H, OCH $\left.H_{2}+H_{6}+\mathrm{NHC}_{\mathrm{q}} \mathrm{CH}_{2} \mathrm{O}+H_{5}\right), 2.11$, 2.08, 2.01, $1.96\left(4 \mathrm{~s}, 324 \mathrm{H}, \mathrm{COCH}_{3}\right) ;{ }^{13} \mathrm{C}\left\{{ }^{1} \mathrm{H}\right\} \mathrm{NMR}(150 \mathrm{MHz}$, 
$\left.\mathrm{CDCl}_{3}\right) \delta(\mathrm{ppm}) 170.6,170.5,170.0,169.9,169.9,169.7,169.6$ $\left(\mathrm{COCH}_{3}\right), 168.4(\mathrm{CONH}), 165.4(\mathrm{CONH}), 144.9+144.8$ $\left(C_{\text {ext-triazole }}\right), 144.5\left(C_{\text {int-triazole }}\right), 135.6\left(C_{\text {arom }}\right), 128.6\left(C \mathrm{H}_{\text {arom }}\right)$, $124.9\left(\mathrm{CH}_{\text {int-triazole }}\right), 124.0\left(\mathrm{CH}_{\text {ext-triazole }}\right), 97.5\left(C_{1}\right), 69.1\left(C_{2}\right)$, $69.0\left(C_{3}\right), 68.7\left(C_{5}\right), 68.4\left(\mathrm{NHC}_{\mathrm{q}} \mathrm{CH}_{2} \mathrm{O}\right), 66.2\left(C_{6}\right), 65.6\left(C_{4}\right)$, $64.5\left(\mathrm{OCH}_{2} \mathrm{C}_{\text {triazole }}\right), 62.1\left(\mathrm{OCH}_{2}\right), 60.4\left(C_{\mathrm{q}}\right), 52.4$ (Ntriazole $\left.\mathrm{CH}_{2} \mathrm{CONH}\right), 49.5\left(\mathrm{CH}_{2} \mathrm{~N}_{\text {triazole }}\right), 20.8,20.8,20.7,20.7$ $\left(\mathrm{COCH}_{3}\right)$; MS ( $\left.{ }^{+} \mathrm{TOF}-\mathrm{MS}, \mathrm{m} / z\right):[\mathrm{M}+\mathrm{H}]^{+}$calculated for $\mathrm{C}_{615} \mathrm{H}_{834} \mathrm{~N}_{120} \mathrm{O}_{318}, 14995.8$; found, 14995.9.

Synthesis of de- $\boldsymbol{O}$-acetylated 27-mer derivative 23: Acetylated compound $22(30.0 \mathrm{mg}, 2.00 \mu \mathrm{mol})$ was dissolved in anhydrous $\mathrm{MeOH}(3 \mathrm{~mL})$ and a solution of sodium methoxide $(1 \mathrm{M}$ in $\mathrm{MeOH}, 5 \mu \mathrm{L}$ every 20 min until precipitation) was added. An additional $100 \mu \mathrm{L}$ was then injected and the heterogeneous reaction mixture was stirred at room temperature for $24 \mathrm{~h}$. The solvent was then removed with a Pasteur pipette and a mixture of anhydrous $\mathrm{MeOH} / \mathrm{DCM}(4: 1,5 \mathrm{~mL})$ was added to the residual white foam. A vigorous agitation is maintained for an additional 15 min period. After removal of the solvent with a Pasteur pipette, the residue was dissolved in $3 \mathrm{~mL}$ of $\mathrm{H}_{2} \mathrm{O}$, and the $\mathrm{pH}$ was adjusted to 7 with addition of ion-exchange resin (Amberlite IR $120 \mathrm{H}^{+}$). After filtration, the solvent was removed under vacuum with a rotary evaporator and lyophilized to yield the fully deprotected 27-mer $\mathbf{2 3}$ as a white solid $(17.0 \mathrm{mg}, 1.63 \mu \mathrm{mol})$ in $82 \%$ yield. ${ }^{1} \mathrm{H} \mathrm{NMR}\left(600 \mathrm{MHz}, \mathrm{D}_{2} \mathrm{O}\right)$ $\delta(\mathrm{ppm}) 8.06(\mathrm{~m}, 3 \mathrm{H}, \mathrm{CH} \mathrm{ar}), 7.97\left(\mathrm{~s}, 27 \mathrm{H}, \mathrm{CH}_{\text {ext-triazole }}\right), 7.96$ (s, $\left.9 \mathrm{H}, \mathrm{CH}_{\text {int-triazole }}\right), 5.14$ (br s, $18 \mathrm{H}, \mathrm{N}_{\text {triazole }} \mathrm{CH}_{2} \mathrm{CONH}$ ), 4.75 $\left(\mathrm{s}, 27 \mathrm{H}, H_{1}\right), 4.59-4.51\left(\mathrm{~m}, 126 \mathrm{H}, \mathrm{OCH}_{2} \mathrm{C}_{\text {triazole }}+\right.$ $\left.\mathrm{N}_{\text {triazole }} \mathrm{CH}_{2}\right), 4.05-4.03\left(\mathrm{~m}, 27 \mathrm{H}, \mathrm{OCH} \mathrm{HCH}_{2} \mathrm{~N}\right), 3.83-3.80(\mathrm{~m}$, $\left.72 \mathrm{H}, \mathrm{OCHHCH}_{2} \mathrm{~N}+\mathrm{H}_{2}+\mathrm{NHC}_{\mathrm{q}} \mathrm{CH}_{2} \mathrm{O}_{\text {int }}\right), 3.71-3.57(\mathrm{~m}$, $\left.162 \mathrm{H}, \mathrm{NHC}_{\mathrm{q}} \mathrm{CH}_{2} \mathrm{O}_{\mathrm{ext}}+H_{6}+H_{4}+H_{3}\right), 3.01\left(\mathrm{~m}, 27 \mathrm{H}, H_{5}\right)$; ${ }^{13} \mathrm{C}\left\{{ }^{1} \mathrm{H}\right\}$ NMR $\left(150 \mathrm{MHz}, \mathrm{D}_{2} \mathrm{O}\right) \delta(\mathrm{ppm}) 168.8\left(C \mathrm{ONH}_{\mathrm{int}}\right)$, $167.5\left(C \mathrm{CNH}_{\text {ext }}\right), 144.7\left(C_{\text {ext-triazole }}\right), 144.6\left(C_{\text {int-triazole }}\right), 135.7$ $\left(C_{\text {arom }}\right), 129.7\left(\mathrm{CH}_{\text {arom }}\right), 127.0\left(\mathrm{CH}_{\text {int-triazole }}\right), 126.1$ $\left(C \mathrm{H}_{\text {ext-triazole }}\right), 100.2\left(C_{1}\right), 73.5\left(C_{5}\right), 71.1\left(C_{3}\right), 70.6\left(C_{2}\right), 68.2$ $\left(\mathrm{NHC}_{\mathrm{q}} \mathrm{CH}_{2} \mathrm{O}\right), 68.0\left(\mathrm{NHC}_{\mathrm{q}} \mathrm{CH}_{2} \mathrm{O}\right), 67.0\left(\mathrm{OCH}_{2} \mathrm{CH}_{2} \mathrm{~N}_{\text {triazole }}\right)$, $66.1\left(C_{4}\right), 64.2\left(\mathrm{OCH}_{2} \mathrm{C}_{\text {triazole }}\right), 61.3\left(C_{6}\right), 60.9\left(C_{\mathrm{q}}\right), 52.9$ $\left(\mathrm{N}_{\text {triazole }} \mathrm{CH}_{2} \mathrm{CONH}\right), \quad 50.7 \quad\left(\mathrm{CH}_{2} \mathrm{~N}_{\text {triazole }}\right), \quad 35.7$ $\left(\mathrm{OCHNCH} \mathrm{C}_{\text {triazole }}\right)$; HRMS ( $\left.{ }^{+} \mathrm{TOF}-\mathrm{HRMS}, \mathrm{m} / \mathrm{z}\right)$ : $[\mathrm{M}+7 \mathrm{H}]^{7+}$ calculated for $\mathrm{C}_{399} \mathrm{H}_{204} \mathrm{~N}_{120} \mathrm{O}_{210}, 1494.6002$; found, 1494.5951 $(\Delta=-3.43 \mathrm{ppm})$.

\section{Supporting Information}

\section{Supporting Information File 1}

Experimental procedures, characterization data, NMR, IR and mass spectra and NMR diffusion experiments. [http://www.beilstein-journals.org/bjoc/content/ supplementary/1860-5397-10-157-S1.pdf]

\section{Acknowledgements}

This work was supported by a discovery grant from the National Science and Engineering Research Council of Canada (NSERC) and by a Canadian Research Chair in Therapeutic Chemistry. YMC is grateful to the FQRNT (Québec) for a scholarship. We are thankful to Dr. A. Furtos (Université de Montréal) for HRMS determination.

\section{References}

1. Roy, R. Curr. Opin. Struct. Biol. 1996, 6, 692-702. doi:10.1016/S0959-440X(96)80037-6

2. Kiessling, L. L.; Gestwicki, J. E.; Strong, L. E. Angew. Chem., Int. Ed. 2006, 45, 2348-2368. doi:10.1002/anie.200502794

3. Imberty, A.; Chabre, Y. M.; Roy, R. Chem.-Eur. J. 2008, 14, 7490-7499. doi:10.1002/chem.200800700

4. Renaudet, O.; Roy, R. Chem. Soc. Rev. 2013, 42, 4515-4517. doi:10.1039/c3cs90029k

5. Kiessling, L. L.; Grim, J. C. Chem. Soc. Rev. 2013, 42, 4476-4491. doi:10.1039/c3cs60097a

6. Bovin, N. V.; Gabius, H.-J. Chem. Soc. Rev. 1995, 24, 413-421. doi:10.1039/cs9952400413

7. Roy, R. Trends Glycosci. Glycotechnol. 2003, 15, 291-310. doi:10.4052/tigg.15.291

8. Roy, R.; Zanini, D.; Meunier, S. J.; Romanowska, A. J. Chem. Soc., Chem. Commun. 1993, 1869-1872. doi:10.1039/C39930001869

9. Chabre, Y. M.; Roy, R. Adv. Carbohydr. Chem. Biochem. 2010, 63, 165-393. doi:10.1016/S0065-2318(10)63006-5

10. Chabre, Y. M.; Roy, R. Curr. Top. Med. Chem. 2008, 8, 1237-1285. doi:10.2174/156802608785848987

11. Lindhorst, T. K. Top. Curr. Chem. 2002, 218, 201-235. doi:10.1007/3-540-45010-6_7

12. Röckendorf, N.; Lindhorst, T. K. Top. Curr. Chem. 2001, 217, 201-238. doi:10.1007/3-540-45003-3_6

13. Roy, R. Polym. News 1996, 21, 226-232.

14. Pieters, R. J. Org. Biomol. Chem. 2009, 7, 2013-2025. doi:10.1039/b901828j

15. Roy, R.; Das, S. K.; Santoyo-González, F.; Hernández-Mateo, F.; Dam, T. K.; Brewer, C. F. Chem.-Eur. J. 2000, 6, 1757-1762. doi:10.1002/(SICI)1521-3765(20000515)6:10<1757::AID-CHEM1757> 3.0.CO;2-5

16. Roy, R.; Trono, M. C.; Giguère, D. ACS Symp. Ser. 2005, 896, 137-150. doi:10.1021/bk-2005-0896.ch008

17. Chabre, Y. M.; Giguère, D.; Blanchard, B.; Rodrigue, J.; Rocheleau, S.; Neault, M.; Rauthu, S.; Papadopoulos, A.; Arnold, A. A.; Imberty, A.; Roy, R. Chem.-Eur. J. 2011, 17, 6545-6562. doi:10.1002/chem.201003402

18. Sirois, S.; Giguère, D.; Roy, R. Med. Chem. 2006, 2, 481-489. doi:10.2174/157340606778250252

19. Gerland, B.; Goudot, A.; Ligeour, C.; Pourceau, G.; Meyer, A.; Vidal, S.; Gehin, T.; Vidal, O.; Souteyrand, E.; Vasseur, J.-J.; Chevolot, Y.; Morvan, F. Bioconjugate Chem. 2014, 25, 379-392. doi:10.1021/bc4005365

20. van Hattum, H.; Branderhorst, H. M.; Moret, E. E.; Nilsson, U. J.; Leffler, H.; Pieters, R. J. J. Med. Chem. 2013, 56, 1350-1354. doi:10.1021/jm301677r

21. Öberg, C. T.; Noresson, A.-L.; Leffler, H.; Nilsson, U. J. Chem.-Eur. J. 2011, 17, 8139-8144. doi:10.1002/chem.201003247 
22. Giguère, D.; André, S.; Bonin, M.-A.; Bellefleur, M.-A.; Provencal, A.; Cloutier, P.; Pucci, B.; Roy, R.; Gabius, H.-J. Bioorg. Med. Chem. 2011, 19, 3280-3287. doi:10.1016/j.bmc.2011.03.022

23. Sharon, N. FEBS Lett. 1987, 217, 145-157. doi:10.1016/0014-5793(87)80654-3

24. Arya, P.; Kutterer, K. M. K.; Qin, H.; Roby, J.; Barnes, M. L.; Kim, J. M.; Roy, R. Bioorg. Med. Chem. Lett. 1998, 8, 1127-1132. doi:10.1016/S0960-894X(98)00182-6

25. Schierholt, A.; Hartmann, M.; Lindhorst, T. K. Carbohydr. Res. 2011, 346, 1519-1526. doi:10.1016/j.carres.2011.04.023

26. Asensio, J. L.; Ardá, A.; Cañada, F. J.; Jiménez-Barbero, J. Acc. Chem. Res. 2013, 46, 946-954. doi:10.1021/ar300024d

27. Chen, W.; Enck, S.; Price, J. L.; Powers, D. L.; Powers, E. T.; Wong, C.-H.; Dyson, H. J.; Kelly, J. W. J. Am. Chem. Soc. 2013, 135, 9877-9884. doi:10.1021/ja4040472

28. Lemieux, R. U. Acc. Chem. Res. 1996, 29, 373-380. doi:10.1021/ar9600087

29. Reynolds, M.; Pérez, S. C. R. Chim. 2011, 14, 74-95. doi:10.1016/j.crci.2010.05.020

30. Dam, T. K.; Roy, R.; Das, S. K.; Oscarson, S.; Brewer, C. F. J. Biol. Chem. 2000, 275, 14223-14230. doi:10.1074/jbc.275.19.14223

31. Dam, T. K.; Roy, R.; Pagé, D.; Brewer, C. F. Biochemistry 2002, 41, 1351-1358. doi:10.1021/bi015830j

32. Munoz, E. M.; Correa, J.; Fernandez-Megia, E.; Riguera, R. J. Am. Chem. Soc. 2009, 131, 17765-17767. doi:10.1021/ja9074826

33. Giguère, D.; Patnam, R.; Bellefleur, M.-A.; St-Pierre, C.; Sato, S.; Roy, R. Chem. Commun. 2006, 2379-2381. doi:10.1039/b517529a

34. Hayes, W.; Osborn, H. M. I.; Osborne, S. D.; Rastall, R. A.; Romagnoli, B. Tetrahedron 2003, 59, 7983-7996. doi:10.1016/j.tet.2003.08.011

35. Touaibia, M.; Wellens, A.; Shiao, T. C.; Wang, Q.; Sirois, S.; Bouckaert, J.; Roy, R. ChemMedChem 2007, 2, 1190-1201. doi:10.1002/cmdc.200700063

36. Chabre, Y. M.; Contino-Pépin, C.; Placide, V.; Shiao, T. C.; Roy, R. J. Org. Chem. 2008, 73, 5602-5605. doi:10.1021/j08008935

37. Cohen, Y.; Avram, L.; Frish, L. Angew. Chem., Int. Ed. 2005, 44, 520-554. doi:10.1002/anie.200300637

38. Berger, S.; Braun, S. 200 and More NMR Experiments-A Practical Course; Wiley-VCH: Weinheim, 2004; pp 145-148.

39. Chabre, Y. M.; Roy, R. Chem. Soc. Rev. 2013, 42, 4657-4708. doi:10.1039/c3cs35483k

40. Cantekin, S.; de Greef, T. F. A.; Palmans, A. R. A. Chem. Soc. Rev. 2012, 41, 6125-6137. doi:10.1039/c2cs35156k

41. Aragão-Leoneti, V.; Campo, V. L.; Gomes, A. S.; Field, R. A.; Carvalho, I. Tetrahedron 2010, 66, 9475-9492. doi:10.1016/j.tet.2010.10.001

42. Finn, M. G.; Fokin, V. V., Eds. Click chemistry: function follows form. Chem. Soc. Rev. 2010, 39, 1221-1408. doi:10.1039/C003740K

43. Corbell, J. B.; Lundquist, J. J.; Toone, E. J. Tetrahedron: Asymmetry 2000, 11, 95-111. doi:10.1016/S0957-4166(99)00589-3

44. Talga, M. L.; Fan, N.; Fueri, A. L.; Brown, R. K.; Chabre, Y. M.; Bandyopadhyay, P.; Roy, R.; Dam, T. K. Biochemistry 2014, in press. doi:10.1021/6i5001307

45. Wu, D. H.; Chen, A. D.; Johnson, C. S., Jr. J. Magn. Reson., Ser. A 1995, 115, 260-264. doi:10.1006/jmra.1995.1176

46. Holz, M.; Weingärtner, H. J. Magn. Reson. 1991, 92, 115-125. doi:10.1016/0022-2364(91)90252-O

47. van Beek, J. D. J. Magn. Reson. 2007, 187, 19-26. doi:10.1016/j.jmr.2007.03.017

\section{License and Terms}

This is an Open Access article under the terms of the Creative Commons Attribution License

(http://creativecommons.org/licenses/by/2.0), which permits unrestricted use, distribution, and reproduction in any medium, provided the original work is properly cited.

The license is subject to the Beilstein Journal of Organic Chemistry terms and conditions:

(http://www.beilstein-journals.org/bjoc)

The definitive version of this article is the electronic one which can be found at:

doi:10.3762/bjoc. 10.157 